\title{
Mapping our way out? Critical reflections on historical research and the 1972 Faure report
}

\author{
Barry J Hake \\ Groningen/Narbonne (eurolearn.hake@gmail.com)
}

\begin{abstract}
Contributions to the literature have postulated an historical shift in policy narratives from the Faure report's formulation of "lifelong education" for UNESCO in 1972 to a focus on "lifelong learning" since the mid-1990s. It has also been argued that the policy narrative articulated by de-schoolers in the early 1970s was incorporated in the Faure report. This paper critically examines the empirical foundations for such arguments and is based on a re-reading of the policy repertoire articulated by Faure's report together with an analysis of the de-schoolers' reception of the report in the early 1970s. Based upon a re-reading of primary texts and secondary sources from the 1970s, the analysis demonstrates that these widely accepted arguments constitute a problematic interpretation of the historical relationships between the key policy narratives in the 1970s. The conclusions identify a number of significant areas for further empirical research regarding the historical relationships between first generation policy narratives.
\end{abstract}

Keywords: Cultural practice, de-schooling, lifelong education, lifelong learning, policy repertoire

'A large part of what passes for adult education theory is an extraordinary combination of sectarianism, special pleading, mythmaking and mortmain' (Williams, 1959, p. 750)

\section{Introduction}

Revisiting the policy narratives of the 1970s is now a well-established habitus among those with an interest in changes in policy prescriptions from the perspective of lifelong education in the 1970s to the current age of lifelong learning (Pineau, 1977; Rozychi,

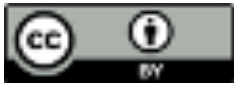


1987; Wain, 1989; Guigou, 1977, 1992; Field, 2001, 2012; Medel-Añonuevo, Ohsako \& Mauch, 2001; Tuijnman \& Boström, 2002; Forquin, 2004; Schütze, 2006; Billett, 2010; Lee \& Friedrich, 2011; Haddat \& Aubin, 2013; Jarvis, 2014; Elfert, 2018). When returning to the policy landscapes of the 1970 s, "lifelong education" is regularly compared with other policy concepts such as "recurrent education", "éducation permanente", "permanent education", and "paid educational leave", but less frequently with "deschooling" society (Alenen, 1982; Duke, 1982; Gelpi, 1984, 1994; Giere, 1994; Boshier, 1998; Istance, Schuetze \& Schuller, 2002; Hager, 2011; Laot, 2009; Zaldívar, 2011, 2015; Bartlett \& Schugurensky, 2020). A major feature of this discourse, however, comprises the identification of a major paradigm shift from lifelong "education" to lifelong "learning".

Since the mid-1990s, research on adult education as a lifelong process has been characterised by a recurrent, if not a permanent, focus on the widely shared diagnosis of an epoch-shaping shift from narratives addressing "lifelong education" to a preoccupation with "lifelong learning" (Barros, 2012; Biesta, 2012; Boshier, 2012 Milana, 2012; Elfert, 2015, 2018, 2019; Fejes \& Nylander, 2019). Mapping these shifting policy paradigms is necessary according to Rubenson (1982, 2006, 2009), who postulates that the 1970s constituted the first of two "generations" of policy development. In similar vein, Hager (2011) refers to first and second "waves" of policy concepts addressing lifelong education and lifelong learning. Others have argued that these generations were marked by significant shifts in "policy vocabularies" from lifelong "education" in the 1970s to lifelong "learning" in the 1990s (Barros, 2012; Milana, 2012). In their contribution to the literature on mapping the field, Fejes and Nylander (2019, p. 3), for example, argue that 'The shift from focusing on education to speaking about learning is important to address in research, because it marks out a new way of conceptualising the education and learning of adults'.

In this context, the 1972 Faure report Learning to be: the world of education today and tomorrow (Faure, Herrera, Kaddoura, Lopès, Pétrovski, Rahnena \& Ward, 1972), serves as a common point of reference for the entire field of research known as "adult education". Furthermore, the majority of studies contributing to the adult education canon specifically argue that UNESCO's policy vocabulary addressing "lifelong education" $a$ la Faure incorporated the critical policy vocabulary of "de-schooling" society as this was voiced by its leading proponents Illich (1970) and Reimer (1971). From a comparative historical perspective, this paper addresses the postulated post-war shift in policy preoccupations from lifelong "education" in the 1970s to lifelong "learning" in the mid1990s. It seeks to offer a critical historiography of the policy formation process surrounding the production and reception of the Faure report as a UNESCO policy document in 1972. Exploring recent contributions to the literature, it constitutes a critical examination of dominant representations of the Faure report regarding the relationships between lifelong education and de-schooling in the 1970s. It questions the empirical validity of widely accepted interpretations of the historical reception of this particular report.

\section{Revisiting the 1972 Faure report: Policy vocabularies, narratives, and repertoires}

Examining the historiography of policy formation since the 1950s, Hake argues that narrative policy analysis offers a potentially fruitful theoretical perspective for research addressing historical transformations of policy vocabularies in relation to the social organisation of communication and learning (Hake 2005; 2011; 2017; 2018; 2019; 2021). For the purposes of comparative historical research, policy narratives can be operationalised as '...ideological representations of arguments advocating the 
redistribution of educational opportunity structures throughout life' (Hake, 2018, p. 783). As social-political phenomena, these policy narratives are historically embedded in the cultural practices of a diverse range of policy actors. These policy actors include international organisations, trans-national polities, governments, ministries, parliaments, political parties, social partners, and educational organisations, but also involve more diffuse policy-relevant actors including the social partners, interest groups, social movements, grass-roots activists, and public intellectuals. Narrative policy analysis examines these narratives by means of empirical research that investigates historical manifestations of these collective "policy repertoires" in terms of their articulation of specific policy strategies, measures, and specific instruments for redistributing learning opportunities. Research subsequently involves description and analysis of partisan policy repertoires that articulate specific policy proposals in reports, documents, submissions of evidence, books, pamphlets, posters, social messaging, protests, demonstrations, and occupation of public space. These cultural repertoires are historically manifested in partisan socio-political struggles concerning the redistribution of learning opportunities over the life course of social groups and individuals. Historical study and analysis of social-political of ideologies as collective structures of argumentation can contribute to the identification of shifts and breaks in the social organisation of "hegemonic", "dominant", "official", "alternative", and "oppositional" cultural repertoires (Williams, 1966, 1981; Jones, 2006; McGuigan, 2019).

From a comparative historical perspective, this paper explores contributions to the literature that articulate the dominant reading of the 1972 Faure report as the "iconic" historical marker of the postulated post-war shift in policy preoccupations from lifelong "education" in the 1970s to lifelong "learning" since the 1990s. It does not seek to offer an in-depth reconstruction of the socio-historical origins, reception, and implementation of the policy repertoires associated with "lifelong education" and "de-schooling". Its more limited and specific purpose is to investigate the empirical basis of recent contributions to the literature with reference to the Faure report's incorporation of deschooling. As such, this article constitutes a critical examination of the adult education literature regarding representations of the Faure report in relation to de-schooling in the early 1970 s.

The following section comprises a review of recent contributions to the literature that propagate the diagnosis of a shift from lifelong education in the 1970s to lifelong learning since the mid-1990s. Section three revisits the 1972 Faure report in order to examine arguments that its policy repertoire incorporated the radical criticism of institutional education as articulated by the de-schoolers. In section four, the de-schoolers' own reception and subsequent critique of Faure's policy repertoire is examined. Section five addresses historical lacunas in the recent literature and suggests priorities for further historical research. This demands a return to primary sources, particularly the text of Faure report itself, together with further empirical research in significant areas. In conclusion, it is argued that critical re-readings of the Faure report were, and remain, available.

\section{Reconstructing Faure's lifelong education narrative}

Regarding the two-generations thesis, Milana (2012, p. 110-111) argues, 'The first of these [generations], from the 1960 s to the 1980 s, was strongly bound to the emerging notion of "lifelong education" as developed by UNESCO.' In the words of Biesta (2005, p. 55), 'One of the most remarkable changes that has taken place over the past two decades in the way in which we speak about [....] education, is the rise of the concept of "learning" and the 
subsequent decline of the concept of "education"”. Likewise, Fejes (2013, p. 99), asserts that 'During the 1990s, we can see how the concept of lifelong education was replaced by lifelong learning within the policy texts.' In similar vein, Barros (2012, p. 120). observes, 'There has been a shift in paradigms from lifelong education, where the concept of education is seen as a collective entity and a state obligation, to lifelong learning, where the concept of learning is seen as an individual entity and a personal duty'.

In relation to such arguments, Faure's 1972 report has been widely recognised as 'the canonical text of the lifelong education movement' (Wain, 2001, p. 184) of the 1970s. According to Milana (2012, p. 109), it 'represented not only a universal principle, but a concrete step towards a democratisation process in education that should lead to the improvement of the quality of life for all'. Likewise, Biesta (2006, p. 171) remarks that Faure's report formulated 'lifelong education in terms of solidarity, democracy and "the complete fulfilment of man"". For some, Faure formulated lifelong education as a "humanist project" embracing a "view of education in its totality as a socio-political and cultural utopia for a more humane society' (Wain, 2001, p. 184). As Fejes (2013, p. 99) notes, 'In the report, we can see how lifelong education is related to a positive humanistic notion of progress and personal development'. In similar vein, Field (2001, p. 6) postulates that 'the Faure report was a turning point. Its essential humanistic concern was with achieving the "fulfilment of man" through flexible organization of the different stages of education'.

Regarding the question of shifting policy vocabularies, Boshier $(1998$, p. 5) remarks that '.. if lifelong education was an instrument for democracy, lifelong learning is almost entirely preoccupied with the cash register'. Likewise, Biesta (2006, p. 172) notes that 'In about three decades, then, the discourse of lifelong learning seems to have shifted from "learning to be" to "learning to be productive and employable"'. This paradigmatic shift from "education" to "learning" has been explained in terms of 'learning to earn' (MedelAñonuevo et al., 2001, p. 1), and the neo-liberal 'mantra of lifelong learning' (Milana, 2012, p. 105), involving 'adaptability and employability' (Fejes, 2013, p. 104). According to Boshier (2012, p. 701), the neo-liberal tendency of 'flying a flag of convenience signals the fact that educational planning has drifted far from the utopian yearnings of the 1970s. [...] Since the 1990s, lifelong education systems have collapsed and mostly been replaced by ad hoc and disconnected manifestations of lifelong learning'. Similarly, Lopez (2014, p. 44) suggests that 'Faure sought to defend an education aimed at the emancipation of the individual and his fulfilment as a human being, and yet, in the decades that followed, such vision has succumbed to the dictates of the neo-liberal state'. Referring to Faure's "utopian vision", Boshier (2012, p. 711) posits that 'By the 1990s, utopian, festive and democratic notions of lifelong education had been replaced by individualized and technologically-mediated notions of learning'. Biesta (2006, p. 171) concludes that Learning to be was a remarkable historical document because the views it expressed 'stand in such sharp contrast to the policies and practices that make up the world of lifelong learning today'. Reiterating such interpretations, Elfert $(2015$, p. 88) posits that the Faure report represents 'a political utopia at odds with current utilitarian policy repertoires'. As Biesta (2021, p. 14) argues, '.... a discourse of education has been replaced by a discourse of learning, thus making education frst and foremost an individual matter - something for individual lifelong learners to take responsibility for - and also making it increasingly a formal matter - something that is about adjustment and adaptation to whatever environment presents itself'.

Such studies have constructed an interpretation of the two-generation thesis based on a paradigm shift from lifelong "education" to lifelong "learning". However, as Field (2001, p. 12) points out 'It is tempting to conclude, as some have done, that the semantic 
shift from "lifelong education" to "lifelong learning" marks a sharp turn towards vocationalism and away from emancipation'. Nevertheless, within this interpretative framework, some subsequently proceed to argue that the Faure Commission's report incorporated the radical de-schooling repertoire of the late 1960s and early 1970s. This particular discursive practice will be subjected to critical scrutiny in the following sections.

\section{Ambiguous architectures: "Lifelong education" embraces "de-schooling"?}

Many proponents of Faure's report articulate its "radical" significance on the grounds that it incorporated the critique of institutionalised education articulated by anarchistic-utopians, neo-Marxists, 1968 activists, and de-schoolers. Regarding shifting vocabularies, Boshier (1998, p. 29) postulates that 'There has been a shift from a neo-Marxist or anarchisticUtopian template' embedded in the Faure report to the hegemonic neo-liberal agenda of lifelong learning in the $21^{\text {st }}$. Referring to May 1968, Lopez $(2014$, p. 44) posits that 'The Faure report $[\ldots]$ seems to have finally embodied many of the concerns and ideals that had paraded down the streets of Paris in 1968'. Even Faure himself has been identified as a representative of the first-generation of 'anarchistic-utopianism and neo-Marxian perspectives' (Boshier, 1998, p. 9). In more general terms, Lee and Friedrich (2011, p. 157) argue that 'Inspired by radical social democrats such as Freire and Illich, the Faure Report mentioned the pedagogical meanings of de-schooling and de-institutionalisation in its critique of conventional educational system'. Boshier (1998; 2004; 2012) persistently argues that Faure was influenced by critics of institutional schooling, including Freire, Goodman, Holt, Illich, Ohligher, Reimer, and Tough. Along similar lines, Lee and Friedrich (2011, p. 157) state that 'this accommodation of radicalist voices is the most distinguishing feature of the Faure report.' Milana (2012, p. 109) also argues that the Faure's report was remarkable because it 'incorporated radical stands (deschooling, de-institutionalisation)'. More recently, Elfert (2019, p. 20) concludes that 'The broader significance of the Faure report lies in it being an expression of a movement driven by socialist and social democratic forces pushing for democratisation and the regulation of capitalism in the 1960s and early 1970s'.

If Faure's report was, as many have argued (Field, 2001; Wain, 2004; Lee \& Friedrich, 2011; Elfert, 2015), the humanistic child of its times, the Faure Commission clearly had problems in making friends. The Commission's introduction referred to four categories of "major trends" in educational development in the volatile worldwide policy environment of the early 1970s. These included, firstly, "educational reformers" involved in 'reforming and reorganising existing education structures and modernising teaching methods' (Faure at al., 1972, p. 19). Secondly, it identified "structural transformations", as 'In countries which more or less recently have gone through social and political upheavals, events have often led to profound structural changes in the educational world, affecting the student base, access to education at various levels, curricula revision and, although to a lesser extent, modernisation of methods' (Faure at al., 1972, p. 19). Their third category referred to "radical criticism" as expressed by proponents of de-schooling of society. Fourthly, the report referred to student and worker activists associated with the events of 1968 in terms of "dissent" (Faure at al., 1972, p. 20).

With its third category, "radical criticism", Faure's report referred to a very mixed bunch of so-called anarchistic-utopian, de-schooling, and neo-Marxist critics of conventional education. Well-known critics, including Freire, Goodman, Illich and Reimer, had been invited to submit papers as evidence to the Commission. While Illich's 
paper, number 38, was entitled 'On the Necessity to De-school Society', papers by Freire, Goodman and Reimer, papers 36, 37 and 39, carried the emblematic common title of 'Unusual Ideas about Education'. Among the 81 documents prepared for the Commission, as recorded in appendix 5, these papers were placed together in Section B: Opinions. In the text of the Faure report, Freire was referred to in three footnotes on pages 75 and 139. While Elfert (2018) posits that Illich was cited several times, these constituted, in fact, two minor footnotes on pages 20 and 21. It remains uncertain as to whether Commission members visited Illich in Mexico to as suggested by the reference in footnote 5 on page 21 to an interview him. Zaldívar $(2011$, p. 64) notes that the outspoken Russian member of the Commission later referred to Illich as unoriginal and an ignoramus (Petrovsky, 1976, pp. 57-61).

In his Preface, Faure articulated the Commission's position regarding aspirations to de-school society as: 'Views of this kind are usually presented as progressive and even revolutionary, but if they were put into practice on any scale, their effects would certainly be of a reactionary nature' (Faure et al., 1972, p. xxxii). In the report itself, de-schoolers were described as "proponents of "deinstitutionalising" education and "de-schooling" society' (Faure et al., 1972, p. 20). The Commission argued that 'Such theses, which as yet have no experimental basis, accordingly remain intellectual speculation' (Faure et al., 1972, p. 20). The de-schoolers arguments were regarded as 'grounded on an outright condemnation of "institutionalised" education and lead either to intermediary formulae or radical plans for a total "de-schooling" of society' (Faure et al., 1972, p. 20). Deschoolers were viewed as supporters of 'this extreme thesis' and 'these novel theories' (Faure et al., 1972, p. 21). Distancing itself from these critics, Faure's Commission, and UNESCO, did not seriously question the role of formal educational institutions in relation to the broader landscape of what was then widely recognised as "out-of-school" learning. Rene Maheu, Director-General of UNESCO, referring indirectly to Illich, remarked: "If the report sometimes evinces sympathy for what might be called the "libertarian myth" in education, the fact remains that the "de-schooling" theory is expressly rejected as Utopian' (Maheu, 1973, p. 5). Rather than embracing the radical repertoire to de-school society, Faure, in his preamble to his Commission's report, emphatically stated that '...schools, that is to say establishments devised to dispense education systematically to the rising generations, are now and will remain in the future...the decisive factor in training men to contribute to the development of society, to play an active part in life, of men properly prepared for work' (Faure et al., 1972, p. xxxii). Although recent contributions reiterate arguments that Faure's report voiced the radical de-schooling repertoire, the report itself was fundamentally dismissive of contemporary practices associated with de-schooling. As such, it was itself not fundamentally critical of pedagogic work of formal education institutions (Finger \& Asún, 2001; Forquin, 2002; Grace \& Rocco, 2009; Zaldívar, 2011; 2015).

Given the vicissitudes of UNESCO politics in the early 1970s, however, Faure's report did not fare well in the short term. Attended for the first time by ministers of education, civil servants, and administrators, rather than academic adult educators and practitioners, the third international conference on adult education in Tokyo, 23 July to 7 August 1972, confirmed the vital contribution of lifelong education in implementing the "learning society", but it focused primarily on policy issues regarding adult literacy and economic development. Ignoring de-schooling, delegates expressed concern that Faure's proposals for alternating education and work subordinated learning to the exigencies of economic productivity, which sounded to them very much like OECD's ongoing embrace of recurrent education for lifelong "learning" (OECD, 1973). UNESCO delegates were reassured that this danger could be averted when lifelong education involved not only 
updating of occupational knowledge and skills but also involved continuing personal development. Nonetheless, as Lowe's (1975, p. 215) report on UNESCO's policymaking concluded, 'There seems little doubt that many governments are committed, however haltingly, to facing up to the operational implications of trying to make educational opportunities available on a recurrent basis, especially with respect to occupational training'.

UNESCO's 1972 general conference, 17 October to 21 November 1972, approved a resolution that 'lifelong education should become the master concept for educational policies in the years to come' (UNESCO, 1973, p. 19). Regarding the Faure report, however, the conference also agreed that 'the report is not an official document of UNESCO, expressing the organisation's policy, but is the report of seven independent experts, published by UNESCO as an important contribution to world-wide discussion on educational development' (UNESCO, 1973, p. 19). Therefore, as the erstwhile 'magnificent seven' (Bengtsson, Berg, Gras, Hake, Hecquet, Lister \& Zimmer, 1975, p. 122), rode off into the policy sunset of a doomed concept, while lifelong learning was already emerging from UNESCO shadows as 'lifelong education and learning', and was enshrined as such by the 1976 Nairobi recommendation on adult education (UNESCO, 1976, p. 2).

\section{Lifelong education as "permanent inadequacy"?}

Faure's lifelong education policy narrative not only encountered scepticism, or was simply ignored, in national and international policy circles (Simmons, 1973), it's ambiguous policy repertoire encountered critique from many academics (Bengtsson et al., 1975), while it was vigorously found wanting particularly by leading proponents of de-schooling. John Ohliger, referred to by Boshier (2004) as one of the key north American anarchistic utopians in adult education, regarded Faure's report as 'just another example of international bureaucratise, although in places the book has a haunting quality strangely akin to a tale of unrequited love' (Ohliger, 1974, p. 47). Regarding Faure's view that 'The normal culmination of the educational process is adult education' (Faure, 1972 p. 204), Ohliger commented dryly 'much more adult education was the only basic reform the report recommended' (Ohliger, 1974, p. 52). Voicing neo-Marxist critique, Carnoy (1974, p. 54) argued that Faure took 'one step forwards and two steps back in thinking about the crisis in education'. Critical of Faure's core assumption that science and technology, particularly its expectations concerning cybernetics, could solve social and educational problems, Carnoy (1974, p. 58), called for a 'defensive education', especially in developing nations, that demanded critical political consciousness and social action as effective strategies to resolve social and educational problems alike.

These radical critics argued that Faure's policy repertoire would extend the compulsory nature of schooling into adulthood. Totalitarian tendencies associated with lifelong education were identified including Faure's argument that 'School education must be regarded not as the end but as the fundamental component of educational activity, which includes both institutionalised and out-of-school education [...]. Briefly, education must be conceived of as an existential continuum as long as life' (Faure et al. 1972, p. 233). Ohliger (1974, p. 56) remarked, 'If I must be oppressed, I don't want to be oppressed by educators. Can you imagine what it would be like with educators, such as the authors of this report, running our lives in a "learning society". While Milana (2012, p. 111) argues that the Faure report was significant because 'lifelong education identifies education with life', critics at the time regarded lifelong education as 'a widely dispersed 
social process that threatened to engulf all social life outside of schools and would guarantee permanent inadequacy' (Ohliger, 1974, p. 54). A contributor to the Council of Europe's work on permanent education, Herman Frese, warned that 'lifelong education would reinforce the established social order, rightly or wrongly; controlling and manipulating the destiny of whole populations' (Frese, 1972, p. 11). At a time when distance education was embracing "open" learning on a broad front, he expressed reservations about Faure's ambitions for using mass media, particularly television, to expand educational provision, when this would involve neo-liberal technocratic control, emergence of commercial interests in the educational marketplace, and monopolies in producing learning materials.

Most telling, however, was the Cuernavaca Manifesto The Price of Lifelong Education (Cidoc, 1974). Responding to Faure's report, twenty-five public intellectuals from 14 countries met at the Centro Intercultural de Documentación, Cuernavaca, Mexico, 22 July-16 August 1974, to discuss a report entitled Present trends towards lifelong education (Guigou, 1975). Signatories of this 'truly disparaging and inflammatory attack on the proponents of lifelong education' (Further, 1977, p. 16) on the Faure report comprised critical public intellectuals, including Carnoy, Guigou, Gorz, Lister, Ohliger, Pineau, Reimer, Verne, Zimmer, and von Hentig. The Manifesto constituted a fundamental critique of Faure's repertoire for expanding the architecture of lifelong education to promote scientific advance and technology in support of economic growth. It argued that Faure, much like OECD on recurrent education, had effectively adopted human resource development as a repertoire for linking lifelong education with work-based training. This repertoire required workers to become more adaptable, flexible, and eager to learn in response to changes in technology and the demands of workplace (Verne, 1976). The Manifesto viewed lifelong education à la Faure as fundamentally shaped by economic requirements, reorganisation of production, exploitive conditions of working life, with learners required to develop themselves to match labour market demands. Arguing that the Faure Commission had not only accommodated economic needs, but had voiced the emergent neoliberal policy repertoire of deregulation, these critics articulated an alternative policy repertoire demanding autonomous social spaces for critical "unlearning to be" to take place in opposition to the mantra voices propagating "learning to earn" in the emergent "information economy" of post-industrial society.

In further responses to Faure's report, Verne (1974), Guigou (1975), Illich and Verne (1976), Dauber and Verne (1976), and Pineau (1977) referred to the threat of imprisonment in the global classroom of lifelong education. They argued that lifelong education, and notions of permanent education, would extend the "educational system" by incorporating out-of-school learning, mutual community learning resources, and autonomous autodidactic learning networks. From the perspective of "autoformation", Pineau (1977) argued that the repertoire envisaged by Faure served to incorporate out-ofschool learning in formal institutional structures, thus threatening to constitute "aliénation permanente". Lynch (1979, p. 6) observed succinctly that 'The concept of lifelong education is not necessarily a danger though it may offer unlimited scope for further subjugation of man to the world of work, in the effort to combat increasing unemployment and to legitimate stubbornly unchanging wealth and income distributions within society and internationally.' 
Re-reading first-generation policy narratives: Crossroads, blind alleys, and diversions

Among contributions to the literature addressing the shift in policy vocabularies since the 1970s, a significant number of studies have postulated that lifelong education $a$ la Faure incorporated the critique of institutionalised education as articulated by the "radical" deschooling repertoire. The analysis here, however, has argued that there is little documented evidence for such claims, indeed, to the contrary, de-schooling was critically dismissed in the Faure report. The Faure Commission, and later UNESCO, explicitly distanced themselves from these so-called "radical influences" and their "utopian ideas". There is, furthermore, overwhelming evidence that Faure's report encountered rigorous critique from ex-1968 militants, free school activists, anarchist-utopians, neo-Marxists, and de-schoolers, but also from mainstream academics.

These findings will be no surprise to those who have actually read the Faure report itself, and who know the secondary literature of the period. Such evidence, however, seems to have escaped many who continue to maintain that Faure's report was a "radical" document. Furthermore, although there is a well-established habit of referring idealistically to the report, this is overwhelmingly based upon reiterative crossreferencing to other recent secondary sources, which repeatedly refer to Faure as the "flagship" or "landmark" report in UNESCO policy formation on lifelong education in the early 1970s. Furthermore, when providing empirical evidence for arguments formulated, there is a disturbing nonchalance with regard to consulting primary sources. Conclusions drawn are more often based upon reiteration of other secondary sources rather than consulting primary sources, particularly the Faure report itself. On these grounds alone, the empirical foundations for the postulated shift in policy vocabularies demonstrates considerable shortcomings. These outcomes, however, do indicate a number of specific areas where further empirical research, based upon primary sources and secondary sources from the 1970s, is required.

There is, firstly, a serious need to the address dominance of English-language contributions to the literature cited in the field of adult education (Fejes \& Nylander, 2014). Dependence upon secondary sources in English contributes to problematic understandings of policy-making processes, policy advocacy, and political activism in different countries and geo-political blocs in global terms (Mazenod, 2017). A particular lacuna is the absence of references in English-language publications to French-language sources relating to the development of "éducation permanente" in France from the mid1950s onwards (Forquin 2002, 2004; Laot 1999, 2009; Hake, 2018). As Centeno (2011) has usefully pointed out, it is vital that more informed historical interpretations examine the political origins of "éducation permanente" in the late 1950s (Hake, 2018), its problematic adoption within UNESCO in the early 1960s (Elfert, 2018), subsequent recognition of "lifelong integrated learning" in the late-1960s (Duke, 1969), Lengrand's (1970) initial translation of "éducation permanente" as "Lifelong Education", and its short-lived transformation by the Faure Commission as "lifelong education" in 1972. Abundant literatures exist in French, German, Portuguese, and Spanish languages with reference to the historical reception and critique of the Faure report, not only in the European context, but also in Africa, South and Central America. This was manifest in complex circuits of cross-cultural production, dissemination, and reception in different languages (Pineau, 1977). Little of this impressive body of international scholarship is cited by the exceptionally parochial 'global' English-language literature.

Secondly, some recent critiques of the neoliberal hegemony in the world of 'adult education' have served to establish a 'a nostalgic orthodoxy involving revisiting the promise of lifelong education during the 1970s' (Hake, 2021, p. 38). This can be best 
understood, in part, as the product of a defensive and nostalgic habitus associated with a long history of "mythmaking" in the world of adult education (Williams, 1959; Chase, 1995; Hughes \& Tight, 1995; Strain \& Field, 1997; Hake, 2021). This mythical tendency involves a collective engagement in celebrating Faure's report, together with UNESCO's "political utopia" of lifelong education (Wain, 2001; Elfert, 2015). Since the late 1980s, Faure's report has become the symbol for 1972 as a 'a year of affirmation for adult education' (Selman, 1989, p. 33). Faure's view of lifelong education has been reconstructed as an idealistic, humanist, and utopian myth. Citing Richmond's (1975, p. xiii) view that Faure's report 'aroused widespread debate on the Continent', Elfert (2019, p. 22) opines, 'The educational literature of the early 1970s contained frequent references to the report'. Historically, however, it is questionable whether 'the Faure report functioned as a catalytic agent for lifelong learning in Western countries' (Elfert, 2019, p. 22). The European Commission, for example, did not produce its' For a Community Policy on Education in 1973 'as a reaction to the Faure report' (Elfert, 2019, p. 22), neither Janne nor the EC referred to Faure (Hake, 2017). Indeed, the argument that 'it is not easy to assess the actual influence of the Faure report as there is very little literature on the subject' (Elfert, 2019, p.22), could mean that Faure's report, in fact, attracted little interest at the time. Richmond, for example, in the same 1975 source cited by Elfert, remarks succinctly that 'Already out of print, it has aroused little interest in the Englishspeaking world and a great deal of unfavourable comment from educationalists at home and abroad' (Richmond, 1975, p. 96.) As Huberman (1979, p. 205) scathingly adds 'lifelong education [...] Is not a concept to which, up to now, academics and the research community has devoted too much time, apart from pointing out its weaknesses and limits'.

Excessive veneration of Faure's report among adult educators tends to constitute an occupational hazard involving the serious failure to recognise the rejection of Faure's report by radical libertarians, anarcho-syndicalists, and neo-Marxists during the 1970s (Guigou, 1975; Pineau, 1977). While it is argued that Faure's report 'has captured the imagination of scholars and educators to this day' (Elfert, 2019, p. 23), this sheds more light, however, on the myth-making habitudes of the "adult education" community itself. One recent accretion to this cottage industry in disciplinary mythmaking comprises the challenging proposition that the intellectually uncomfortable neologism of an "unfailure" can be of use when seeking to explain the historical absence of a positive reception for Faure's humanistic vision of lifelong education (Elfert, 2019, p. 18, p. 23). Biesta (2021, p. 1) goes one step further in contributing to myth-building, when he argues that the Faure report reclaimed a future for education '...that has not yet been'. Indeed, collective veneration for lifelong education during the 1970s has contributed to a veritable 'cultural formation' (Williams, 1981, p. 138) among a faction of adult educators, which actively contributes to mythmaking surrounding Faure's report. Myths, however, need no historical evidence to exert their influence; mythmaking is not scholarship. Research is required, however, that critically investigates mythical tendencies in some quarters of the academic world of "adult education".

There is a need, thirdly, to re-read Faure's report regarding its call for continued economic growth to reduce social inequalities (Lajeunesse, 1974). Published in the same year as Limits to Growth (Meadows, Meadows, Randers \& Behrens, 1972), the Faure Commission rejected growing concerns in the early 1970s with unregulated exponential economic, population growth, and finite natural resources as was argued by the Meadows Report. Indeed, Faure's own preamble argued 'Some minds do not hesitate to suggest a total cessation of growth - zero growth [...] without going openly to this extreme point to advocate, in the form of an ecological policy, a renaissance of Malthusianism' (Faure et 
al., 1972, p. xxxii). He proposed that economic growth needed to be compatible with the quality of life and human balance. According to Pineau (1977, p. 290), 'this same rationality animates a scientific humanism for which knowledge of salvation is no longer in the sky or the sun but in the laboratory' [translation Hake]. This manifested Faure's personal a vision of future for education which embraced industrial and technological efficiency, and which articulated Faure's political position supporting a 'liberal educational offensive' (Jadotte, 1973, p. 3). Faure's report advocated invasive use of mass media and learning technologies, including out-of-school learning networks, facilitated by nation-states, to promote learning throughout life, everywhere. De-schooling critics regarded this as a repertoire for promoting lifelong education as 'a widely dispersed social process that threatened to engulf all social life outside of schools and would guarantee permanent inadequacy' (Ohliger, 1974, p. 54).

Indeed, when revisited more closely, the epochal shift from education to learning was announced by Faure, himself a radical liberal politician, and his Commission, which shared the then widely held 'progressive' ideology of a cybernetic vision of information society (Webster \& Robins, 1989). Recognising second chance education's embrace of distance learning on a broad front in the early 1970s, Faure's report combined utilising mass media with extending educational provision. This was a liberal vision of cybercapitalism that ignored issues concerning technocratic control, commercial interests in the educational marketplace, and emergent monopolies in producing learning materials (Hake, 2021). Faure embraced "purposeful learning activities" stressing out-of-school learning and utilising mass media as modernising technologies in promoting learning. Presenting his report to UNESCO, 25 September 1972, Faure stressed that democratising access to education demanded willingness to use modern educational technologies to expand the provision of "learning" throughout life (Le Monde, 1972). Faure actively propagated a shift from education to learning involving greater co-ordination and control promised by the mass media, with a future featuring algorithms and cybernetics dominating pages $102,105,106,115,143,144$ of the Faure report. These were core elements of Faure's modernising policy repertoire that promised 'the rebuilding of the educational city to allow learning to be' (Pineau, 1977, p. 290). Research is required that investigates the primacy granted by the Faure Commission to scientific knowledge and technology, particularly automated production, with its references to the promise of cybernetics serving the information economy, while it ignored the controlling dimensions of communications and the threat of a putative surveillance society (Hake, 2021).

Fourthly, it is vitally necessary to revisit the very diverse ideological-political repertoires that were articulated in the world of policy narratives the during the 1960s and 1970s (Hake, 2021). These included varieties of "anarchist", "libertarian", "situationist", "syndicalist", "socialist", "communist" including Maoist, "social-democratic", "new left", "corporatist", "liberal", "ecological" repertoires, together with emergent neoliberal policy narratives from the early 1970s (Bengtsson et al., 1975; Forquin, 2004; Guigou, 1971, 1973a, 1977; Hake, 2021; Laot, 2009; Pineau, 1977; Wolin, 2010). Faure and his Commission have been frequently associated in the literature with a variety of political affiliations including '...radical social democrats' (Lee \& Friedrich, 2011, p. 157), while Elfert $(2015,2018)$ persists with more recent references to both '... social democratic liberalism' (2019, p. 18), and to '... socialist and social democratic forces' (2019, p. 20). As noted earlier, Faure himself has been associated in the literature with a variety of political positions including representing the first-generation of 'anarchistic-utopianism and neo-Marxian perspectives' (Boshier, 1998, p. 9). Closer to the historical record, most published references tend to identify Faure with the left-of-centre in the French political spectrum. Indeed, Faure himself has been identified as 'a French socialist politician' 
(Elfert, 2019, p. 19). Disciplinary veracity demands, however, that historians distance themselves from these widely accepted accounts regarding Faure's social-political position in post-war French political life during his long career as a well-respected and erudite "public intellectual".

A long-serving French career politician, Edgar Faure (1908-1988) was "un homme politique" (Krakovitch, 2006), a pragmatist and opportunist, was originally elected for the right-of-centre liberal Radical Party. He led conservative elements in this socially "liberal" party, held Ministerial office many times in the Fourth Republic, briefly as Prime Minister in 1952 and 1955, but always in right-of-centre governments (Lestrohan, 2007). Faure's own centre-right coalition cabinet was defeated in January 1956 to be replaced by a socialist-led coalition, which almost immediately passed the first legislation in France regulating "éducation permanente" (Hake, 2018). A skilled exponent of 'managerial pragmatism' in politics (Loriaux, 1991, p. 149), Faure, joined the Gaullists in 1958, becoming an influential politician during the Fifth Republic.

As Minister of Education 1968-1969, Faure succeeded in securing right-wing Gaullist support for his albeit very moderate reforms of universities (Patterson, 1972; Fomerand, 1977). In 1969, Faure addressed the Paris meeting of the Council of Europe's Standing Conference of Ministers, where Olaf Palme, Swedish Minister of Education, explained Swedish recurrent education policies (Rubenson, 1994). During this meeting, Faure presented French policy for "éducation permanente", but, according to Bengtsson (2013), Palme's advisor on recurrent education at the time, without a strategy as to how it was to be implemented. He was dismissed in late 1969 following the resignation of General de Gaulle. Faure chaired UNESCO's commission 1971-1972, subsequently becoming Minister of Social Affairs, 1972-1973, and was Chairman of the National Assembly 1973-1978.

Although Faure was known, and indeed admired in some quarters, as the perennial weathercock of post-war French politics given his ability to successfully serve governments of diffuse political plumage, this categorically excluded socialist-led governments. Throughout his career, Faure refused to serve in coalition governments led by the French left-wing social-democratic party, Parti socialiste (PS); the party Jacques Delors joined in 1974 on returning to active party politics. Invited, in 1981, to support Mitterand's socialist coalition government, Faure refused, as noted by Lee and Friedrich (2011) in their footnote 6, on the grounds that the President was prepared to co-operate with the Parti communiste français (PCF). This suggests that questions concerning the veracity of references to the socialist pedigree of Faure himself, let alone the Faure report demand far more nuanced historical analysis of the political ideologies and policy repertoires at work in transnational and national educational policy networks during the early 1970 s.

\section{En route to lifelong learning: unexplored connections}

This paper has investigated interpretations of the relationships between first- and secondgeneration policy narratives with particular reference to "lifelong education" and "deschooling" as policy repertoires. Exploring these relationships, it focused on a critical rereading of Faure's report regarding its supposed incorporation of de-schoolers' critique of institutional education, and the de-schoolers critical reception of the Commission's report. The findings identify serious shortcomings regarding the historical foundations of widely shared interpretations of first-generation narratives. This critical re-reading suggests that dutifully mapping the "adult education" canon is inadequate when tracing 
historical relationships between policy repertoires during the 1970s. It identifies the need for critical perspectives on often unexplored connections. Furthermore, the analysis here gives rise to serious reservations concerning the broader interpretative framework postulating that shifts of policy paradigms from lifelong "education" to lifelong "learning" have taken place, and the historical character of these shifts. Many accepted accounts offer no more than a historical teleology, while sustained historiographical analysis of contesting political repertoires is required in order to establish residual, emergent, hegemonic, oppositional, and alternative cultural repertoires (Williams, 1981).

Likewise, the recurrent education narrative of the 1970s is regarded by some as still alive and doing since the early 1990s well in the hands of OECD and the EU in the form of the neoliberal lifelong learning policy repertoire (Borg \& Mayo, 2005; Biesta, 2006; Barros, 2012; Milana, 2012; Nicholl \& Olesen, 2013). Rather than focusing on the post1990 s, however, research is needed that examines how the failure of social democratic repertoires in the early 1970 s created a political vacuum that was adroitly occupied by emergent neoliberal repertoires articulating the reconstruction of capitalism based on deregulated learning in the workplace, aided by weak responses by national governments to the 1973 global oil crisis (Prasad, 2006; Levinson, 2016). This calls for serious reconsideration of Faure's proto-neoliberal technocratic embrace of 'maximum vocational mobility' (Faure et al., 1972, p. 196), which, with its focus on workplace learning and invasive mass media, threatened to make lifelong education a quotidian requirement for all in a credentialed and mobile workforce.

Critical historical perspectives on policy repertoires suggests that comparative policy research also needs to seriously reconsider contributions to the literature that postulate radically different policy significations of "lifelong education" in the Faure Report for UNESCO in 1972 and OECD's 1973 report on "recurrent education" (Milana, 2012; Fejes, 2013; Boshier, 1998; Barros, 2012; Medel-Añonuevo et al., 2001). Rereading Faure's report demonstrates that it systematically and approvingly appropriated "recurrent education" as a policy repertoire, in the French translation as" éducation récurrente" and "éducation iterative". Historically informed policy research is required calling for further empirical research regarding the Faure Commission's position concerning the recurrent education repertoire developed in Sweden in the late 1960s and its adoption by OECD in 1973.

Revisiting "lifelong education" in the age of "lifelong learning" appears to be a hazardous process. As Field (2001, p. 12) reflects, 'It is tempting to conclude, as some have done, that the semantic shift from "lifelong education" to 'lifelong learning' marks a sharp turn towards vocationalism and away from emancipation'. This paper has suggested that overarching questions about the historical relationships between first- and second-generation policy narratives still have to be posed, let alone convincingly answered. Recent contributions addressing the two generations have failed to generate rigorous historical research needed to explore issues of continuity and discontinuity in public policy formation. In the words of Williams (1959), the canon of adult education remains characterised by special pleading and mythmaking. Research is now needed that contributes more informed understandings of the historical and contemporary sociopolitical conditions in which policy repertoires articulated social justice and sought to redistribute adult learning throughout the life course. Further research is needed to investigate both historical and contemporary struggles to collectively organise opportunity structures that are capable of mobilising engagement in "really useful learning" throughout the life course in the tough times of financial capitalism in the crisis of the early $21^{\text {st }}$ century. This will require, however, a more sound empirical basis for a critical historiography which makes it possible to disentangle the history of past political 
struggles from the distorting myths that might serve some current academic agendas rather than historical scholarship.

\section{References}

Alenen, A. (1982). Lifelong education-permanent education-recurrent education. Adult Education in Finland, 19(2), 3-41.

Bartlett, T., \& Schugurensky, D. (2020). Deschooling Society 50 Years Later: Revisiting Ivan Illich in the Era of COVID-19. Sisyphus 8(3), 65-84.

Barros, R. (2012). From lifelong education to lifelong learning: Discussion of some effects of today's neoliberal policies. European Journal for Research on the Education and Learning of Adults, 3(2), 119-134.

Bengtsson, J. (2013). National strategies for implementing lifelong learning (LLL) - the gap between policy and reality: An international perspective. International Review of Education, 59(3), 343-352.

Bengtsson, J., Berg, v.d. A., Gras, A., Hake, B.J., Hecquet, I., Lister, I., \& Zimmer, J. (1975). Does Education Have a Future? The Political Economy of Social and Educational Inequalities in European Society. The Hague: Nijhoff.

Biesta, G. (2005). Against learning: Reclaiming a language for education in an age of learning. Nordisk Pedagogik, 25, 54-66.

Biesta, G. (2006). What's the Point of Lifelong Learning if Lifelong Learning Has No Point? On the Democratic Deficit of Policies for Lifelong Learning. European Educational Research Journal, $5(3 / 4), 169-180$

Biesta, G. (2012). Have lifelong learning and emancipation still something to say to each other? Studies in the Education of Adults, 44(1), 5-20.

Biesta, G. (2021). Reclaiming a future that has not yet been: The Faure report, UNESCO's humanism and the need for the emancipation of education. International Review of Education. https://doi.org/10.1007/s11159-021-09921-x

Billett, S. (2010). The perils of confusing lifelong learning with lifelong education. International Journal of Lifelong Education, 29(4), 401-413.

Borg, C., \& Mayo, P. (2005). The EU Memorandum on lifelong learning. Old wine in new bottles? Globalisation, Societies and Education, 3(2), 203-225.

Boshier, R. (1998). Edgar Faure after 25 years: down but not out. In J. Holford, P. Jarvis, \& C. Griffin (Eds.), International Perspectives on lifelong Learning (pp.3-20). London: Kogan Page.

Boshier, R. (2004). Meanings and manifestations of anarchist-utopian ethos in adult education. Proceedings 45th Annual Adult Education Research Conference (AERC), Victoria, B.C., 53-58.

Boshier, R. (2012). Lifelong Learning as a Flag of Convenience. In D.N. Aspin, J. Chapman, K. Evans \& R. Bagnall (Eds.), Second International Handbook of Lifelong Learning (pp. 701-719). Dordrecht: Springer.

Carnoy, M. (1974). Learning to Be: Consensus and Contradictions. Convergence, 7(3), 53-60.

Centeno, V. (2011). Lifelong learning: a policy concept with a long past but a short history. International Journal of Lifelong Education, 30(2), 133-150.

Cidoc (1974). The price of lifelong education. Doc. I/V 74/70, Cuernavaca: Center for Intercultural Documentation.

Chase, M. (1995). 'Mythmaking and Mortmain': The Uses of Adult Education History? Studies in the Education of Adults, 27(1), 52-65.

Dauber, H., \& Verne, E. (1976) (Eds.). Freiheit zum Lernen. Alternativen zur lebenslänglichen Verschulung. Die Einheit von Leben, Lernen, Arbeiten. Reinbek bei Hamburg: Rowohlt.

Duke, C. (1969). Towards éducation permanente: The Concept of Life-long Integrated Education. Australian Journal of Adult Education, 9(3), 103-13.

Duke, C. (1982). Evolution of the Recurrent Education Concept. International Journal of Lifelong Education, 1(4), 323-340.

Elfert, M. (2015). UNESCO, the Faure Report, the Delors Report, and the Political Utopia of Lifelong Learning. European Journal of Education, 50(1), 88-100.

Elfert, M. (2018). UNESCO's Utopia of Lifelong Learning: An Intellectual History. Abingdon: Routledge.

Elfert, M. (2019). Revisiting the Faure Report and the Delors Report: Why Was UNESCO's Utopian Vision of Lifelong Learning an "Unfailure"? In F. Finnegan \& B. Grummell (eds). Power and Possibility: Adult Education in a Diverse and Complex World (pp. 17-25). Leiden: Brill. 
Faure, E., Herrera, P., Kaddoura, A-K., Lopès, H., Pétrovski, A.V., Rahnena, M., \& Ward, F.C. (1972). Learning to be: the world of education today and tomorrow. Paris: UNESCO/Harrop.

Fejes, A. (2013). Lifelong learning and employability. In G. Zarifis, \& M.N. Gravani (Eds), Challenging the 'European Area of Lifelong Learning': A Critical Response (pp. 99-107). Dordrecht: Springer.

Fejes, A. \& Nylander, E. (eds) (2019). Mapping out the Research Field of Adult Education and Learning. Heidelberg: Springer.

Field, J. (2001). Lifelong education. International Journal of Lifelong Education 20(1/2), 3-15.

Field, J. (2012). Transitions in Lifelong Learning: Public Issues, Private Troubles, Liminal Identities. Studies for the Learning Society, 2(2/3), 4-11. |

Finger, M., \& Asún, J. M. (2001). Adult Education at the Crossroads: Learning our way out. London: Zed Books.

Fomerand, J. (1977). The French University: What Happened after the Revolution? Higher Education, 6(1), 93-116.

Forquin, J.-C. (2002. Les composantes doctrinales de l'idée d'éducation permanente. Analyse thématique d'un corpus international. Paris: L'Harmattan.

Forquin, J-C, (2004). L'idée d'éducation permanente et son expression internationale depuis les années 1960. Savoirs, 3(6), 9-44.

Frese, H. (1972). Permanent Education - Dream or Nightmare? Education and Culture, 19, 9-13.

Further, P. (1977). The planner and lifelong education. Paris: International Institute of Educational Planning.

Gelpi, E. (1984). Lifelong education: Opportunities and obstacles. International Journal of Lifelong Education, 3(2), 79-87.

Gelpi, E. (1994). L'éducation permanente: principe révolutionnaire et pratiques conservatrices. International Review of Education, 40(3), 343-351.

Giere, U. (1994). Lifelong Learners in the Literature: Adventurers, Artists, Dreamers, Old Wise Men, Technologists, Unemployed, Little Witches and Yuppies. International Review of Education, 40(3/5), 383-393.

Grace, A. P., Rocco, T. S., \& Associates (2009). Challenging the Professionalisation of Adult Education: John Ohliger and Contradictions in Modern Practice. San Francisco: Jossey-Bass.

Guigou, J. (1971). L'école désétatisée. Combat, 3 mars.9

Guigou, J. (1992). Critique des systèmes de formation des adultes, 1968-1992. Paris: Harmattan

Guigou, J. (1973). Critique de l'analyse systématique des actions de formation. Ėducation Permanente, 17, $113-146$

Guigou, J. (1975). Les coûts de l'éducation permanente: un été avec Illich (août 1974). L'Homme et la société, 35, 225-237.

Guigou, J. (1977). L'institution de la formation permanente. In G. Pineau (Ed.), Education ou aliénation permanente ?: repères mythiques et politiques (pp. 190-206). Paris: Dunod.

Guigou, J. (1992). Critique des systèmes de formation des adultes, 1968-1992. Paris : Harmattan

Grace, A.P., \& Rocco, T.S. (Eds) (2009). Challenging the Professionalization of Adult Education: John Ohliger and Contradictions in Modern Practice. San Franciso: Jossey-Bass.

Haddat, G., \& Aubin, J-P. (2013). Towards a humanism of knowledge, action, and co-operation. International Review of Education, 59(3), 331-334.

Hager, P.J. (2011). Concepts and Definitions of Lifelong Learning. In M. London (ed.), The Oxford Handbook of Lifelong Learning (pp. 12-25). Oxford: Oxford UP.

Hake, B.J. (2005). Fragility of the Employability Agenda: Flexible life courses and the reconfiguration of lifelong learning in The Netherlands. In A. Bron, E. Kurantowicz, H. Salling Olesen, \& L. West (eds), 'Old' and 'new' worlds of adult learning (pp. 234-253). Wroclaw: Wydawnictwo Naokowe.

Hake, B.J. (2011). Rewriting the History of Adult Education: The Search for Narrative Structures. In K. Rubenson (Ed.), Adult Learning and Education (pp.14-19). Oxford: Academic Press.

Hake, B.J. (2017). Strange encounters on the road to lifelong learning: the European economic community meets permanent education in 1973. History of Education, 46(4), 514-532.

Hake, B.J. (2018). Éducation permanente in France en route to 'permanent education' at the Council of Europe? Revisiting a projet social to create 'a long life of learning', History of Education, 47(6), 779-805.

Hake, B.J. (2019). L'éducation permanente et le Conseil de l'Europe: le rôle oublié des réseaux français. Education Permanente, $n^{\circ}$ 220-221, 295-314.

Hake, B.J. (2021). Looking forward backwards: Varieties of capitalisms, alternative futures, and learning landscapes. European journal for Research on the Education and Learning of Adults, 12(1), 31-45.

Huberman, M. (1979). Live and Learn: A Review of Recent Studies in Lifelong Education. Higher Education, 8(2), 205-215. 
Hughes, C., \& Tight, M. (1995). The myth of the learning society. British Journal of Educational Studies, 43(3), 290-304.

Illich, I. (1970). Deschooling Society. New York: Harper and Row.

Illich, I., \& Verne, E. (1976). Imprisoned in the Global Classroom. London: Writers and Readers Publishing Co-operative.

Istance, D., Schuetze, H.G., \& Schuller, T. (2002). International perspectives on lifelong learning: From recurrent education to the knowledge society. Buckingham: SRHE/OU.

Jadotte, H. (1973). Le Rapport Faure: une offensive du libéralisme éducatif. Forum, 7(23), 3.

Jarvis, P. (2014). From adult education to lifelong learning and beyond. Comparative Education, 50(1), 4557.

Jones P. (2006). Raymond Williams's Sociology of Culture. London: Palgrave Macmillan.

Krakovitch, R. (2006). Edgar Faure: le virtuose de la politique. Paris : Economica.

Lajeunesse, M. (1974). Le Rapport Faure et l'idée de changement. Documentation et bibliothèques, 20(1), 27-33.

Laot, F. F. (1999). La formation des adultes. Histoire d'une utopie en acte. Le Complexe de Nancy. Paris : L'Harmattan.

Laot, F.F. (2009). Focusing on the idea of Permanent Education in France and its Progressive Decline. In A Heikkinen, \& K. Kraus (Eds.), Reworking vocational education: policies, practices, and concepts (pp. 121-140). Bern: Peter Lang.

Lee, M. L., \& Friedrich, T. (2011). Continuously reaffirmed, subtly accommodated, obviously missing and fallaciously critiqued: ideologies in UNESCO's lifelong learning policy. International Journal of Lifelong Education, 30(2), 151-169.

Le Monde (1972). M. Edgar Faure présente son rapport sur l'avenir de l'éducation. Le Monde, September 27, 1972.

Lengrand, P. (1970). An Introduction to Lifelong Education. Paris: UNESCO.

Lestrohan, P. (2007). L'Edgar: Biographie d'Edgar Faure. Paris: Le Cherche Midi.

Levinson, M. (2016). An Extraordinary Time: The End of the Post-war Boom and the Return of the Ordinary Economy. New York: Basic Books.

Lister, I. (1974). Deschooling: a reader. London: Cambridge University Press.

Lopez, A. (2014). The University as power or counter-power? May 1968 and the emergence of a new learning subject. European Journal for Research on the Education and Learning of Adults, 5(1), 31-49.

Loriaux, M.M. (1991). France After Hegemony: International Change and Financial Reform. Ithaca: Cornell University Press.

Lowe, R. (1975). The Education of Adults: A World Perspective. Paris and Toronto: UNESCO Press and Ontario Institute for Studies in Education.

Lynch, M. (1979). Education for Community: A Cross-cultural Study in Education. London: Macmillan.

Maheu, R. (1973). An aid to reflection for necessary renovations. Prospects, 3(1), 51-56.

Mazenod, A. (2017). Lost in translation? Comparative education research and the production of academic knowledge. Compare: A Journal of Comparative and International Education, 48(2), 189-205

Medel-Añonuevo, C., Ohsako, T., \& Mauch, W. (2001). Revisiting Lifelong Learning for the $21^{\text {st }}$ Century. Hamburg: UNESCO Institute for Education.

McGuigan, J. (2019). Raymond Williams: Cultural Analyst. Bristol: Intellect Books.

Meadows, D.H., Meadows, D.L., Randers, J., \& Behrens III (1972). The limits to growth: A report for the club of Rome's project on the predicament of mankind. New York: Universe Books.

Milana, M. (2012). Political globalisation and the shift from adult education to lifelong learning. European Journal for Research on the Education and Learning of Adults, 3(2), 103-117.

Nicholl, K., \& Olesen, H. (2013). What's new in a new competence regime? European Journal for Research on the Education and Learning of Adults, 4(2), 103-109.

OECD (1973). Recurrent Education: A Strategy for Lifelong Learning. Paris: Centre for Educational Research and Innovation.

Ohliger, J. (1974). Is Lifelong Education a Guarantee of Permanent Inadequacy? Convergence, 7(2), 4759.

Patterson, M. (1972). French University Reform: Renaissance or Restoration? Comparative Education Review, 16(2), 281-302.

Petrovsky, A. V. (1976). What lies behind de-schooling? Prospects, 6(1), 60-64.

Pineau, G. (Ed.) (1977). Éducation ou aliénation permanente?: repères mythiques et politiques. Paris: Dunod.

Prasad, M. (2006). The Politics of Free Markets: The Rise of Neoliberal Economic Policies in Britain, France, Germany, and the United States. Chicago: University of Chicago Press. 
Reimer, E. (1971). School is Dead: Alternatives in Education. An Indictment of the System and a Strategy of Revolution. Harmondsworth: Penguin.

Richmond, W.K. (1975). Education and Schooling. London: Routledge.

Rubenson, K. (1982). Adult Education Research: in Quest of a Map of the Territory. Adult Education, $32(2), 57-74$.

Rubenson, K. (1994). Recurrent education policy in Sweden: A moving target. International Review of Education, 40, 245-256.

Rubenson, K. (2006). Constructing the lifelong learning paradigm: Competing visions from the OECD and UNESCO. In S. Ehlers (ed.), Milestones towards lifelong learning systems (pp. 151-170). Copenhagen: Danish School of Education.

Rubenson, K. (2009). OECD educational policies and world hegemony. In R. Mahon, \& S. McBride (Eds.), The OECD and transnational governance (pp. 96-116). Vancouver: UBC Press.

Schütze, H. G. (2006). International concepts and agendas of Lifelong Learning. Compare: A Journal of Comparative and International Education, 36(3), 289-306.

Selman, G. (1989). 1972 - Year of Affirmation for Adult Education. Canadian Journal for the Study of Adult Education/la Revue Canadienne pour l'etude de l'education des adultes, 3(1), 33-45.

Simmons, J. (1973). The Report of the Faure Commission: One Step Forward and Two Steps Back. Higher Education, 2(4), 475-488.

Strain, M., \&. Field, J. (1977). On the Myth of the Learning Society. British Journal of Educational Studies, 45(2), 141-155.

Tuijnman, A., \& Boström, A.K. (2002). Changing notions of lifelong education and lifelong learning. International Review of Education, 48(1), 93-110.

Verne, E. (1974). Une Scolarisation sans fin. Revue Esprit, 10, 529-546.

Verne, E. (1976). Literacy and industrialisation-the dispossession of speech. In L. Bataille (ed.), A Turning Point for Literacy (pp. 211-218). Oxford: Pergamon.

UNESCO (1973). Records of the General Conference, 17th session, Paris, 17 October to 21 November 1972, v. 1: Resolutions, p. 18.

UNESCO (1976). Recommendation on the development of adult education adopted by the General Conference at its nineteenth session Nairobi, 26 November 1976.

Wain, K. (1989). The Case of Lifelong Education - A Reply to Rozycki. Educational Theory, 39(2), 151162.

Wain, K. (2001). Lifelong Learning: Small Adjustments or Paradigmatic Shift? In D. Aspin, J. Chapman, M. Hatton, \& Y. Sawano (eds.), International Handbook of Lifelong Learning (pp.183-198). Dordrecht: Kluwer Academic Publishers.

Wain, K. (2004). The Learning Society in a Postmodern World. Frankfurt: Peter Lang.

Webster, F., \& Robins, K. (1989). Plan and Control: Towards a Cultural History of the Information Society. Theory and Society, 18(3), 323-351.

Williams, R. (1959, May 30). Going on learning. New Statesman, (pp. 750-751).

Williams, R. (1966). Communications. London : Penquin.

Williams, R. (1981). Culture. London: Fontana.

Wolin, R. (2010). The Wind from the East: French Intellectuals, the Cultural Revolution, and the Legacy of the 1960s. Princeton: Princeton University Press.

Zaldívar, J. (2011). Revisiting the critiques of Ivan Illich's Deschooling Society. International Journal for Cross-Disciplinary Subjects in Education, 1(1), 618-626.

Zaldívar, J. (2015). Deschooling for all? The thought of Ivan Illich in the era of education (and learning) for all. Foro de Educación, 13(18), 93-109. 